Prepared for the U.S. Department of Energy under Contract DE-AC05-76RL01830

\title{
Advanced Metering Plan for Monitoring Energy and Potable Water Use in PNNL EMS4 Buildings
}

\author{
JE Pope \\ NJ Olson \\ MJ Berman \\ DR Schielke
}

August 2011

Pacific Northwest

NATIONAL LABORATORY

Proudly Operated by Battelle Since 1965 


\title{
DISCLAIMER
}

This report was prepared as an account of work sponsored by an agency of the United States Government. Neither the United States Government nor any agency thereof, nor Battelle Memorial Institute, nor any of their employees, makes any warranty, express or implied, or assumes any legal liability or responsibility for the accuracy, completeness, or usefulness of any information, apparatus, product, or process disclosed, or represents that its use would not infringe privately owned rights. Reference herein to any specific commercial product, process, or service by trade name, trademark, manufacturer, or otherwise does not necessarily constitute or imply its endorsement, recommendation, or favoring by the United States Government or any agency thereof, or Battelle Memorial Institute. The views and opinions of authors expressed herein do not necessarily state or reflect those of the United States Government or any agency thereof.

\author{
PACIFIC NORTHWEST NATIONAL LABORATORY \\ operated by \\ BATTELLE \\ for the \\ UNITED STATES DEPARTMENT OF ENERGY \\ under Contract DE-ACO5-76RL01830
}

Printed in the United States of America
Available to DOE and DOE contractors from the
Office of Scientific and Technical Information,
P.O. Box 62, Oak Ridge, TN 37831-0062;
ph: (865) 576-8401
fax: (865) 5765728
email: reports@adonis.osti.gov

\author{
Available to the public from the National Technical Information Service, \\ U.S. Department of Commerce, 5285 Port Royal Rd., Springfield, VA 22161 \\ ph: (800) 553-6847 \\ fax: (703) 605-6900 \\ email: orders@nits.fedworld.gov \\ online ordering: http://www.ntis.gov/ordering.htm
}




\title{
Advanced Metering Plan for Monitoring Energy and Potable Water Use in PNNL EMS4 Buildings
}

\author{
JE Pope \\ NJ Olson \\ MJ Berman \\ DR Schielke
}

August 2011

Prepared for

the U.S. Department of Energy

under Contract DE-AC05-76RL01830

Pacific Northwest National Laboratory

Richland, Washington 99352 


\section{Executive Summary}

This updated Advanced Metering Plan for monitoring whole building energy use in Pacific Northwest National Laboratory (PNNL) EMS4 buildings ${ }^{1}$ on the PNNL campus has been prepared in accordance with the requirements of the Energy Policy Act of 2005 (EPAct 2005), Section 103, U.S. Department of Energy (DOE) Order 430.2B, and Metering Best Practices, A Guide to Achieving Utility Resource Efficiency, Federal Energy Management Program, October 2007 (Sullivan et al. 2007). The initial PNNL plan was developed in July 2007 (Olson 2007), updated in September 2008 (Olson et al. 2008), updated in September 2009 (Olson et al. 2009), and updated again in August 2010 (Olson et al. 2010).

The PNNL EMS4 buildings included in the plan for advanced metering are all current buildings expected to be retained after 2012. They consist of the Environmental and Molecular Sciences Laboratory (EMSL), Physical Sciences Laboratory (PSF, new 2010), four 300 Area buildings, Laboratory Storage Warehouse (LSW, new 2011), the leased Biological Sciences Facility-Computer Sciences Facility (BSF-CSF, new 2010) and 10 other leased buildings. These buildings are addressed in detail in Section 2.0.

Advanced Electrical metering has been completed for all scheduled EMS4 buildings (Table 1). Potable water was advanced metered in FY 2009-FY 2010 at the 318, 331, and 350 buildings to meet the baselining and other requirements of DOE Order 430.2B because potable water was not metered previously in the 300 Area. Water at the 325 Building was advanced metered in FY 2011. The main water supply to the EMSL building is now advanced metered, and a second line supplying the EMSL administrative wing is scheduled to be advanced metered in FY 2011. In FY 2009-FY 2011, natural gas advanced metering was completed for the 318, 325, 331, 3475, and EMSL buildings to validate billings and to obtain an accurate baseline history. The new BSF-CSF buildings were constructed with advanced metering for electricity, water, and natural gas. Water and natural gas advanced meters are planned for installation in late 2011 and early 2012 for the individual buildings that make up the PSF Complex. Standard meters for potable water and natural gas are in place for the rest of the EMS4 leased buildings.

This update shows that PNNL has made considerable advanced metering installation progress (Table 1). The plan is to provide advanced electrical and natural gas metering on $96 \%$ of the total EMS4 Buildings square footage. To date, $100 \%$ of the electrical portion of the plan, which has a completion goal in 2012, has been completed. Natural gas metering, with a completion goal in 2016, is scheduled to be complete in 2012. In addition, advanced water meters have been installed in EMSL and the 300 Area buildings. The leased buildings have standard water meters. PNNL will use the advanced metering data to monitor building energy and water use and improve energy and water efficiency for enhanced facility operation.

\footnotetext{
${ }^{1}$ EMS4 = Energy Management Systems Version 4. EMS4 is a DOE database to track energy usage in federally owned or leased facilities and is updated annually.
} 


\section{Contents}

Executive Summary ...............................................................................................................

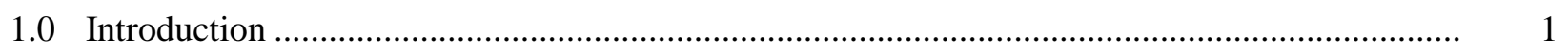

2.0 Analyses of Existing Facilities ....................................................................................... 2

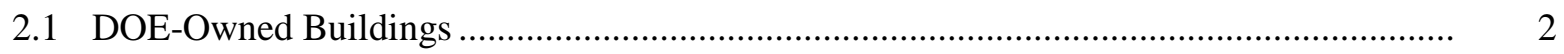

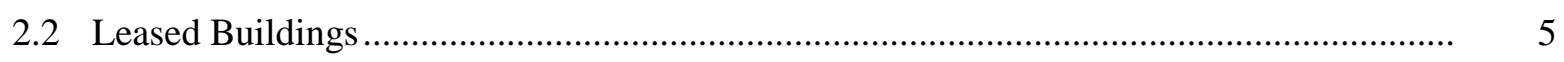

3.0 Advanced Metering Plan and Schedule.......................................................................... 5

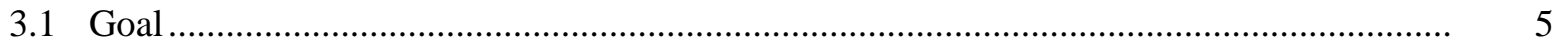

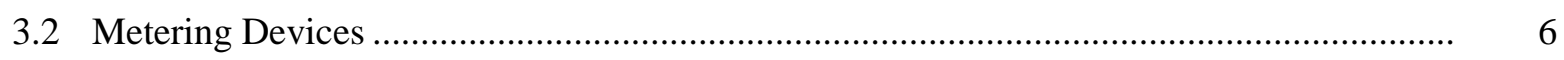

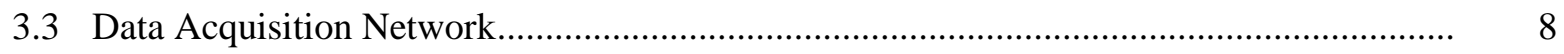

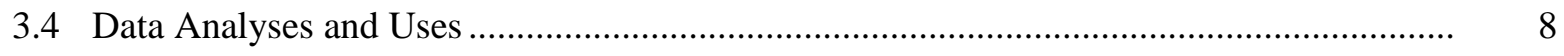

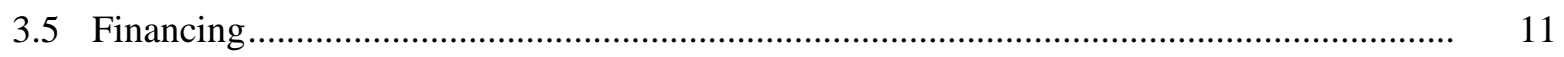

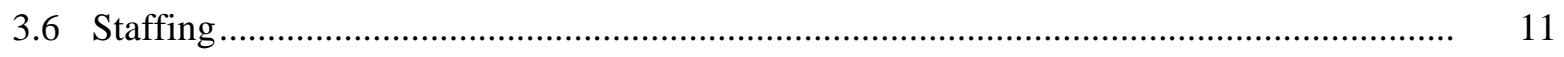

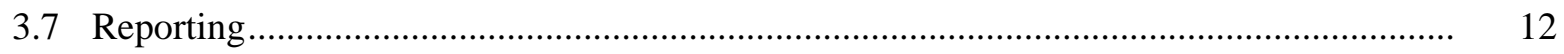

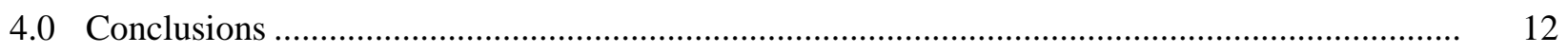

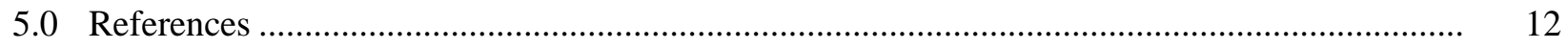

\section{Figures}

1 Schematic Diagram of the PRO-MON Instrumentation Deployed in PNNL Leased

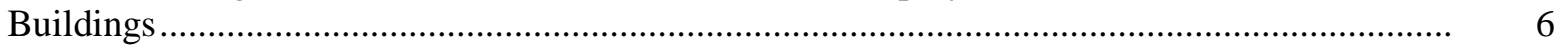

2 Schematic Diagram of the Pulse Splitter/Metasys Controller Deployed in Some

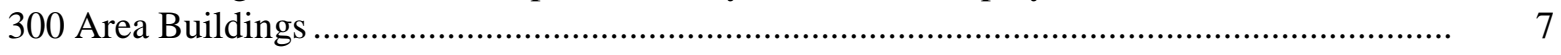

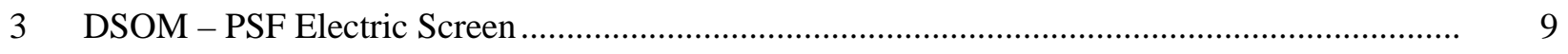

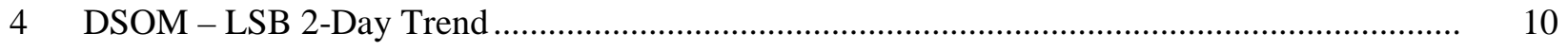

$5 \quad$ Building Operations Control Center ...................................................................................... 11

\section{Table}

1 Installed Advanced Meter Technologies for PNNL EMS4 Buildings 


\subsection{Introduction}

The Energy Policy Act of 2005 (EPAct 2005), Section 103, required all federal buildings to install practical and cost-effective meters and advanced electric metering systems by October 1, 2012. Pacific Northwest National Laboratory's (PNNL's) first requirement was to submit a metering plan by July 2007 (Olson 2007). Due to changes in objectives and progress, the PNNL plan was updated in 2008 (Olson et al. 2008), in 2009 (Olson et al. 2009), and in 2010 (Olson et al. 2010). This update defines the progress made thus far.

The U.S. Department of Energy (DOE) previously determined that EPAct 2005, Section 103, pertains only to electric metering and leaves, for example, natural gas metering to the discretion of the user. However, the Energy Independence and Security Act of 2007 (EISA 2007) extends the requirements for building metering, and DOE Order 430.2B expands metering "to the maximum extent practicable, the contractor must install metering for devices that measure consumption of potable water, electricity, steam, and natural gas in each building and other facilities and grounds." In addition, DOE Order 430.2B requires reducing energy intensity by at least 30 percent by 2015 compared to a 2003 baseline. It also requires reducing potable water use by at least 16 percent by 2015 compared to a 2007 baseline. The advanced metering installed or to be installed to meet these requirements is described in this metering plan.

DOE Order 430.2B requires at least daily data collection capability for meters. In the Federal Energy Management Program (FEMP) sponsored Metering Best Practices, A Guide to Achieving Utility Resource Efficiency, October 2007 (Sullivan et al. 2007), advanced meters are defined as those meters that have the capability to measure and record interval data (at least hourly for electricity), and communicate these data to a remote location in a format that can be easily integrated into an advanced metering system, which includes data acquisition and analyses.

An advanced metering system collects time-differentiated energy usage data from advanced meters via a network system on either an on-request or defined schedule basis. The system must be capable of providing usage information on at least a daily basis and support desired features and functionality related to energy use management, procurement, and operations.

For planning purposes, the FEMP guidance estimated that electrical cost savings depends on the metering strategy, which can be separated into four levels of metering:

1. Simply installing standard meters - 0 to 2 percent energy savings.

2. Metering for billing allocation-2.5 to 5 percent energy savings. The savings are due to improved awareness, which results in remedial actions.

3. Metering for building tune-up -5 to 15 percent energy savings. The savings are due to improved awareness and the identification of simple operation and maintenance (O\&M) improvements.

4. Metering for continuous commissioning-15 to 45 percent energy savings. The savings are due to improved awareness, identification of O\&M improvements, implementation of energy conservation/ efficiency measures, and continuous management attention. 


\subsection{Analyses of Existing Facilities}

The PNNL EMS4 buildings included in the plan for advanced metering are all current buildings expected to be retained after 2012. They consist of the Environmental and Molecular Sciences Laboratory (EMSL), Physical Sciences Facility (PSF), four 300 Area buildings, the leased Biological Sciences Facility-Computer Sciences Facility (BSF-CSF), and 10 other leased buildings.

\subsection{DOE-Owned Buildings}

\section{EMSL}

Electrical metering points (General Electric Power Meters) have been installed at EMSL (discussed in Section 3.2) on each of the three main service feeders and added to obtain the total electrical consumption and demand for the building every 15 minutes. The $\mathrm{kW}$ data are transmitted to Metasys and are displayed on the Decision Support for Operations and Maintenance (DSOM) website where they can be accessed for analyses.

Potable water at EMSL from the main (west) meter is monitored by transmitting pulses from the local water meter to the Metasys system downloading pulse data in DSOM. The south meter is currently a standard water meter and construction is underway to advance meter this location. The whole building natural gas meter is connected to Metasys and DSOM. The technical details are given in Sections 3.2.-3.4.

\section{PSF Complex}

The new PSF was completed in FY 2010 and FY 2011. The PSF complex is composed of five separate buildings (3410, 3420, 3425, 3430, and 3440) totaling 245,000 $\mathrm{ft}^{2}$ of space (Table 1). Advanced metering for electricity in each individual building was included in the original construction and use GE meters which transmit data to Metasys. Natural gas and water are metered at the complex level. Designs are underway to meter natural gas and water for each building individually with installation of these meters expected to be complete in FY 2012. Electricity consumption for each building is displayed on DSOM.

The new Laboratory Storage Warehouse (LSW) was completed in FY 2011. The LSW uses a pulse signal from the City of Richland electric meter that transmits data to Metasys. Advanced metering of natural gas in the LSW is complete and uses a Datus pulse meter connected to Metasys. Water usage is measured using a standard meter. Electricity and natural gas consumption in the LSW are displayed on DSOM.

\section{Area Buildings}

The 300 Area buildings to be retained after 2012 are the 318, 325, 331, and 350 buildings. Electricity for each of these buildings and their various associated outbuildings is supplied from the 300 Area site electrical distribution systems. Until FY 2009, there were no potable water meters for these buildings. In FY 2009-FY 2010, pulse meters were installed for monitoring natural gas and potable water. A general 
description of the monitoring opportunities and progress for the other DOE buildings is covered in this section, and technical details are given in Sections 3.2-3.4.

Table 1. Installed Advanced Meter Technologies for PNNL EMS4 Buildings

\begin{tabular}{|c|c|c|c|c|c|}
\hline Building & $\begin{array}{c}\text { Building } \\
\text { Square } \\
\text { Footage }\left(\mathbf{f t}^{2}\right)\end{array}$ & $\begin{array}{l}\text { Advanced Power Meter Technology } \\
\text { Installed or to be Installed }\end{array}$ & $\begin{array}{l}\text { Electrical } \\
\text { Meter } \\
\text { Schedule }\end{array}$ & $\begin{array}{l}\text { Gas Meter } \\
\text { Schedule }\end{array}$ & $\begin{array}{l}\text { Water } \\
\text { Meter } \\
\text { Schedule }\end{array}$ \\
\hline EMSL-3020 & 224,463 & $\begin{array}{l}\text { Whole Building Electric - GE, Metasys } \\
\text { and DSOM, Gas - Metasys and DSOM, } \\
\text { Water-Metasys and DSOM }\end{array}$ & Completed & Completed & FY 2012 \\
\hline 318 & 37,025 & $\begin{array}{l}\text { Whole Building Electric -Veris, } \\
\text { Metasys and DSOM, Potable Water- } \\
\text { Badger, Metasys and DSOM, Gas- } \\
\text { Datus, Metasys and DSOM }\end{array}$ & Completed & Completed & Completed \\
\hline 325 & 144,820 & $\begin{array}{l}\text { Whole Building Electric -Cutler } \\
\text { Hammer, Metasys and DSOM, Potable } \\
\text { Water-Onicon, Metasys and DSOM, } \\
\text { Gas-Datus, Metasys and DSOM }\end{array}$ & Completed & Completed & Completed \\
\hline 331 & 115,127 & $\begin{array}{l}\text { Whole Building Electric -MSA Utility } \\
\text { Splitter, Metasys and DSOM, Potable } \\
\text { Water-Badger, Metasys and DSOM, } \\
\text { Gas-Datus, Metasys and DSOM }\end{array}$ & Completed & Completed & Completed \\
\hline 350 & 22,048 & $\begin{array}{l}\text { Whole Building Electric -MSA Utility } \\
\text { Splitter, Metasys and DSOM, Potable } \\
\text { Water-Badger, Metasys and DSOM }\end{array}$ & Completed & N/A & Completed \\
\hline 3410 & 79,878 & $\begin{array}{l}\text { Whole Building Electric - GE, Metasys } \\
\text { and DSOM, Potable Water - Badger, } \\
\text { Metasys and DSOM, Gas - Datus, } \\
\text { Metasys and DSOM }\end{array}$ & Completed & FY 2012 & FY 2012 \\
\hline 3420 & 81,369 & $\begin{array}{l}\text { Whole Building Electric - GE, Metasys } \\
\text { and DSOM, Potable Water - Badger, } \\
\text { Metasys and DSOM, Gas - Datus, } \\
\text { Metasys and DSOM }\end{array}$ & Completed & FY 2012 & FY 2012 \\
\hline 3425 & 7,418 & $\begin{array}{l}\text { Whole Building Electric - GE, Metasys } \\
\text { and DSOM, Potable Water - Badger, } \\
\text { Metasys and DSOM, Gas - Datus, } \\
\text { Metasys and DSOM }\end{array}$ & Completed & FY 2012 & FY 2012 \\
\hline 3430 & 70,298 & $\begin{array}{l}\text { Whole Building Electric - GE, Metasys } \\
\text { and DSOM, Potable Water - Badger, } \\
\text { Metasys and DSOM, Gas - Datus, } \\
\text { Metasys and DSOM }\end{array}$ & Completed & FY 2012 & FY 2012 \\
\hline 3440 & 5,488 & $\begin{array}{l}\text { Whole Building Electric - GE, Metasys } \\
\text { and DSOM, Potable Water - Badger, } \\
\text { Metasys and DSOM, Gas - Datus, } \\
\text { Metasys and DSOM }\end{array}$ & Completed & FY 2012 & FY 2012 \\
\hline LSW & 20,092 & $\begin{array}{l}\text { Whole Building Electric - City of } \\
\text { Richland Pulse, Metasys and DSOM, } \\
\text { Gas - Datus, Metasys and DSOM }\end{array}$ & Completed & Completed & $\begin{array}{l}\text { Standard - } \\
\text { Installed }\end{array}$ \\
\hline 2400 Stevens & 99,626 & Whole Building Electric-PRO-MON & Completed & N/A & $\begin{array}{l}\text { Standard - } \\
\text { Installed }\end{array}$ \\
\hline ETB & 100,358 & Whole Building Electric-PRO-MON & Completed & N/A & $\begin{array}{l}\text { Standard - } \\
\text { Installed }\end{array}$ \\
\hline ISB I & 50,200 & Whole Building Electric-PRO-MON & Completed & N/A & $\begin{array}{l}\text { Standard - } \\
\text { Installed }\end{array}$ \\
\hline
\end{tabular}


Table 1. (contd)

\begin{tabular}{|c|c|c|c|c|c|}
\hline Building & $\begin{array}{c}\text { Building } \\
\text { Square } \\
\text { Footage }\left(\mathbf{f t}^{2}\right)\end{array}$ & $\begin{array}{c}\text { Advanced Power Meter Technology } \\
\text { Installed or to be Installed }\end{array}$ & $\begin{array}{l}\text { Electrical } \\
\text { Meter } \\
\text { Schedule }\end{array}$ & $\begin{array}{l}\text { Gas Meter } \\
\text { Schedule }\end{array}$ & $\begin{array}{c}\text { Water } \\
\text { Meter } \\
\text { Schedule }\end{array}$ \\
\hline ISB II & 60,080 & $\begin{array}{l}\text { Whole Building and Data Center } \\
\text { Electric-PRO-MON }\end{array}$ & Completed & N/A & $\begin{array}{l}\text { Standard - } \\
\text { Installed }\end{array}$ \\
\hline LSB & 83,921 & $\begin{array}{l}\text { PRO-MON (Whole Building Electric), } \\
\text { WESCON (Whole Building and Data } \\
\text { Center Electric) }\end{array}$ & Completed & N/A & $\begin{array}{l}\text { Standard - } \\
\text { Installed }\end{array}$ \\
\hline NSB & 100,358 & Whole Building Electric-PRO-MON & Completed & N/A & $\begin{array}{l}\text { Standard - } \\
\text { Installed }\end{array}$ \\
\hline Sigma I & 20,000 & Whole Building Electric-PRO-MON & Completed & N/A & $\begin{array}{l}\text { Standard - } \\
\text { Installed }\end{array}$ \\
\hline Sigma II & 20,100 & Whole Building Electric-PRO-MON & Completed & N/A & $\begin{array}{l}\text { Standard - } \\
\text { Installed }\end{array}$ \\
\hline Sigma III & 20,090 & $\begin{array}{l}\text { Whole Building Electric - Metasys and } \\
\text { PRO-MON. K-20(all electrical use } \\
\text { categories) }\end{array}$ & Completed & N/A & $\begin{array}{l}\text { Standard - } \\
\text { Installed }\end{array}$ \\
\hline Sigma IV & 20,530 & Whole Building Electric-PRO-MON & Completed & N/A & $\begin{array}{l}\text { Standard - } \\
\text { Installed }\end{array}$ \\
\hline Sigma V & 47,900 & $\begin{array}{l}\text { Whole Building and Data Center } \\
\text { Electric-PRO-MON }\end{array}$ & Completed & N/A & $\begin{array}{l}\text { Standard - } \\
\text { Installed }\end{array}$ \\
\hline BSF-CSF & 148,700 & $\begin{array}{l}\text { Whole Building and Submetering - } \\
\text { Square D Power Logic Ion Enterprise- } \\
\text { Data Collection System \& Alerton } \\
\text { System }\end{array}$ & Completed & Completed & Completed \\
\hline $\begin{array}{l}\text { Total Retained EMS4 } \\
\text { Facilities Advanced } \\
\text { Meters (Electrical and } \\
\text { Gas) - Planned }\end{array}$ & $1,579,889$ & $96.2 \%$ & & & \\
\hline $\begin{array}{l}\text { Total Retained EMS4 } \\
\text { Facilities }\end{array}$ & $1,642,239$ & $100 \%$ & & & \\
\hline $\begin{array}{l}\text { Total Retained EMS4 } \\
\text { Facilities Advanced } \\
\text { Meters (Electrical and } \\
\text { Gas) - Planned and } \\
\text { Completed }\end{array}$ & $1,335,438$ & $84.5 \%$ & & & \\
\hline
\end{tabular}

A single metering point is located in substation E3S-18 for the 318 Building. This metering point captures consumption and demand for the 318 Building and associated additions as well as the Trailer 4 complex. The Trailer 4 complex consists of four connected sections of modular buildings housing a small instrument shop and offices. At present, Trailer 4 is lightly occupied. Separate metering of this complex is not warranted. Veris meters are installed in the switchgear and communicate data to Metasys. Natural gas is monitored using a Datus meter connected to Metasys. Potable water is metered with a Badger compound meter also connected to Metasys. Electricity, natural gas, and water consumption are all displayed on DSOM.

The 325 Building has two Cutler Hammer meters connected to Metasys that are totaled to account for the building usage. Power to the 325 Chiller Building is measured by adding totals from meters on the two chillers and two pumps in the chiller building. Natural gas is metered using Datus pulse meters also 
connected to Metasys. Water is metered using three Onicon pulse meters connected to Metasys and totaled to get the whole building usage. Electricity, natural gas, and water consumption are displayed on DSOM.

The 331 Building has three Hanford meters with pulsed output. Two meters are totaled to account for total building electrical usage and a third meter measures the chiller electrical usage. Data from the Hanford pulse meters is collected in Metasys. Natural gas usage is monitored using Datus pulse meters which transmit pulses to Metasys. A Badger pulse meter has been installed for potable water and transmits pulses which are received by the Metasys system. Electricity, natural gas, and water use are displayed on DSOM.

The 350 Building complex has one electrical metering point. Pulses from the Hanford meter are transmitted to Metasys. Water use is measured using a Badger pulse meter with pulses transmitted to Metasys. The 350 building has no gas service. Electricity and water usage are displayed on DSOM.

\subsection{Leased Buildings}

The leased buildings with advanced meters—2400 Stevens; Environmental Technology Building (ETB); Information Science Buildings (ISB I and II); Laboratory Support Building (LSB); National Security Building (NSB); and Sigma I, II, III, IV, and V use E-MON PRO-MON advanced meters which record power usage within the meter. Data from EMON meters are transmitted to DSOM daily. Standard meters for whole building potable water usage are in place as well as for natural gas usage, where used.

The new Biological Science Facility-Computer Science Facility (BSF-CSF) was completed in FY 2010. Commercial advanced metering is provided by the Square D Power Logic Ion Enterprise-Data Collection system and the Alerton system. Advanced metering was included in the design of these facilities. Efforts are underway to transfer data from the facilities' advanced metering system (Alerton) to DSOM with completion scheduled in FY 2012. The BSF-CSF complex is composed of two buildings with a common main entry totaling $148,700 \mathrm{ft}^{2}$ of space (Table 1 ).

\subsection{Advanced Metering Plan and Schedule}

\subsection{Goal}

The primary goal of this plan is use advanced metering data to monitor building energy and potable water use to improve energy efficiency and water conservation. This plan focuses on providing total (whole) building energy consumption and demand metering on an individual whole building basis without extensive submetering for end-use categories, except for major data centers. As PNNL gains experience on whole buildings or pilot submetering in a limited number of buildings, submetering for end-use categories will be reviewed, as appropriate, from a position of need and potential payback. All Sigma III end-use categories as well as heating, ventilation, and air conditioning (HVAC) systems have been submetered for a pilot study to determine the value of submetering. There is also some emphasis on submetering data centers in DOE Order 430.2B. Therefore, PNNL has submetered the data centers in ISB II and LSB with the objective of better managing energy use in PNNL's data centers. 


\subsection{Metering Devices}

The advanced metering devices used are described in this section. PNNL uses a number of different metering devices, depending on the location and infrastructure. For whole building electrical service metering in EMSL, PNNL installed General Electric GE H8025 Series Enercept power meters. These GE devices on the EMSL Switch Gear require a "black box" converter that is compatible with the Metasys N2 communications bus. Metasys is the primary control system used by PNNL and can transmit data to a central server for analyses and data storage. The current transformers are attached directly to the conductors being metered and automatically detect and compensate for phase reversal. Additional enclosures were not required to install these devices. Wiring from the devices is connected to appropriate input points on Metasys field devices. Devices are sized based on the maximum capacity of the electrical service or distribution branch being metered.

The PRO-MON instrumentation (manufactured by the E-MON company) is connected to split core current transformers located in the building electrical panels and records data for 11 of the leased buildings-Sigma 1, 2, 3, 4, 5, LSB, 2400 Stevens, ETB, ISB I, ISB II, and NSB (Figure 1). Data is stored in the meter's processor and is available to access through an analog phone line using E-MON software which has incorporated analytical tools. The analog phone line also allows data to be downloaded to DSOM daily.

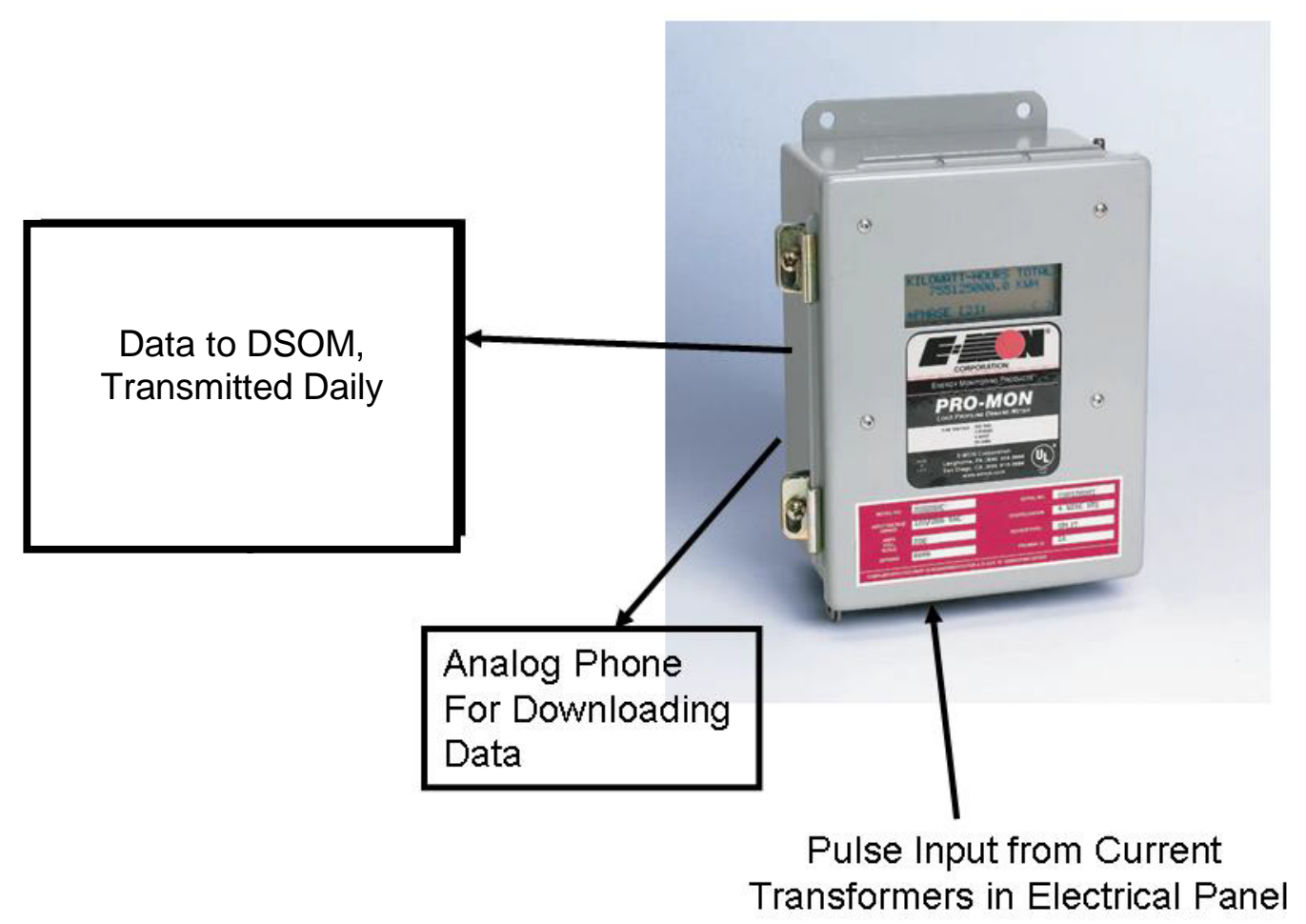

Figure 1. Schematic Diagram of the PRO-MON Instrumentation Deployed in PNNL Leased Buildings

In LSB, split core transformers (current and voltage) with Wescon ACU Multi-Circuit Power Meters communicating via a MODBUS network with a Campbell Scientific CR1000 data logger have also been installed for whole building and for submetering rooftop HVAC units as well as data center energy usage. 
A Campbell data logger performs all the data storage and communication functions for the network. Currently, the data are transmitted by analog telephone to a central server on a daily basis. This instrumentation continuously stores kW, kWh, Amps, Power Factor, and Kvar in 15-minute time intervals.

During FY 2008, PNNL evaluated several electrical-usage data acquisition technologies and settled on PRO-MON Power Meter-Data Logger (manufactured by the E-MON company) advanced meters for electrical use monitoring in buildings when suitable. Suitability factors include not requiring conductor determination for current transformer installation and accessibility to electrical panels for installing current transformers.

In summary, the PRO-MON technology stores $\mathrm{kW}$ for more than a month at 15-minute intervals, which can be transmitted by analog or wireless phone, cell phone, LAN, or wireless LAN to a central server. These data also can be manually downloaded into a personal computer and analyzed with E-MON software. Data are currently stored on the DSOM site where they are available for analyses.

The buildings being serviced by the Hanford Site utility contractor, Mission Support Alliance, LLC (MSA), have instrumentation installed to transmit pulses back to the utility to measure consumption (Figure 2). In the 331 Building and 350 Building, a pulse splitter was installed that allows the MSA pulse to be duplicated, sending one pulse to the MSA instrumentation and one pulse to the building's Metasys controller. Pulses received by the Metasys controller can be accumulated and displayed on DSOM for analysis.

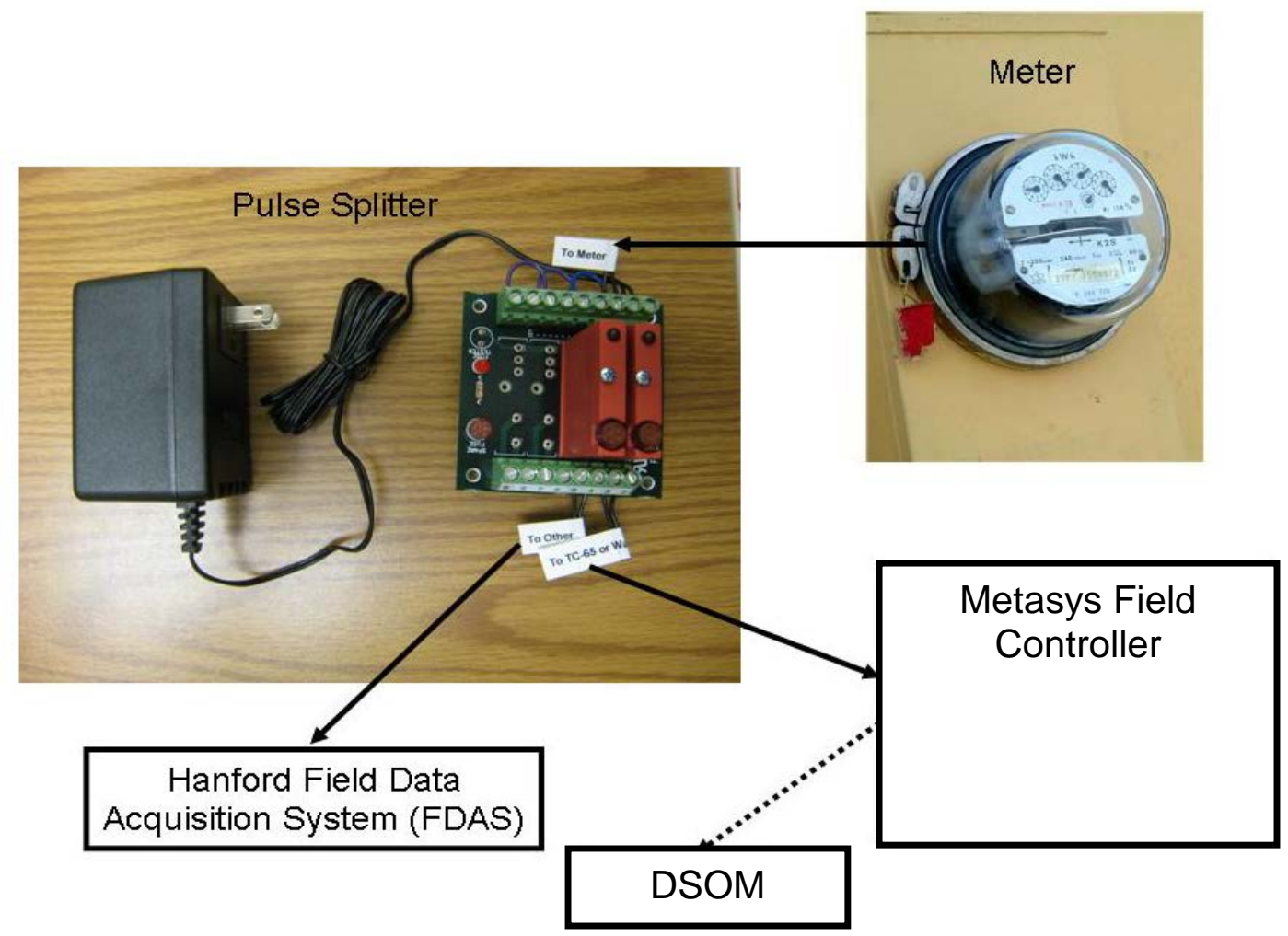

Figure 2. Schematic Diagram of the Pulse Splitter/Metasys Controller Deployed in Some 300 Area Buildings 
The 318 Building uses a Veris meter that is installed on the incoming bus in the service equipment. The Veris meter measures power along with many other electrical data points and communicates this data to the Metasys system via the N2 bus. Data is available to view in Metasys and DSOM, with a more expanded data set available on Metasys.

The 325 Building uses the Cutler Hammer meters that were installed with the switchgear to measure electrical data. Data from the Cutler Hammer meters is routed through an integrator with an N2 bus output so it can be read by the Metasys system. The Danfoss variable frequency drives (VFD) connected to the pumps in the chiller building transmit electrical data to Metasys via the N2 bus, as do the Veris meters connected to the chiller feeds.

\subsection{Data Acquisition Network}

Developed by PNNL, the DSOM system is an advanced supervision and diagnostic tool to reduce plant operating and maintenance costs and extend plant life.

Linking plant operators, maintenance staff, engineers, and administrators in one enterprise-wide system, DSOM combines online condition monitoring and control of equipment with unique diagnostic routines. Originally created for efficient operation of nuclear power plants, the science at the core of DSOM has been adapted to cost effectively meet the needs of industrial processes, including power plants, continuous industrial processes plus facility plants, HVAC systems, and today’s metering.

DSOM is built around the concept of condition-based management. DSOM's diagnostic capabilities prompt operators to make changes to keep systems operating at peak performance and avoid degradation and failures. It has successfully been integrated with standard sensor technology plus more advanced systems like vibration monitoring, laser systems, ultrasonic monitoring system and utility meter plus sub metering.

Field experience has validated that cost reductions of 20 to 40 percent can be realized through improved process efficiency, reduced O\&M workload, reduced maintenance parts and labor, reduced energy consumption, and equipment life extension.

DSOM is now being integrated into the PNNL daily operations and tracking of energy goals.

\subsection{Data Analyses and Uses}

In FY 2011, PNNL made an effort to move data collection, storage, and analysis tools from the NorthWrite Building Solutions service to DSOM. PNNL is using a custom version of the DSOM program developed at PNNL and described above as an analytical tool for monitoring electrical, natural gas, and potable water use. An example for the PSF complex electricity use is shown in Figure 3. Figure 4 shows the trending available for a single meter, the example showing a 2-day trend of kW vs. time for the LSB building. 


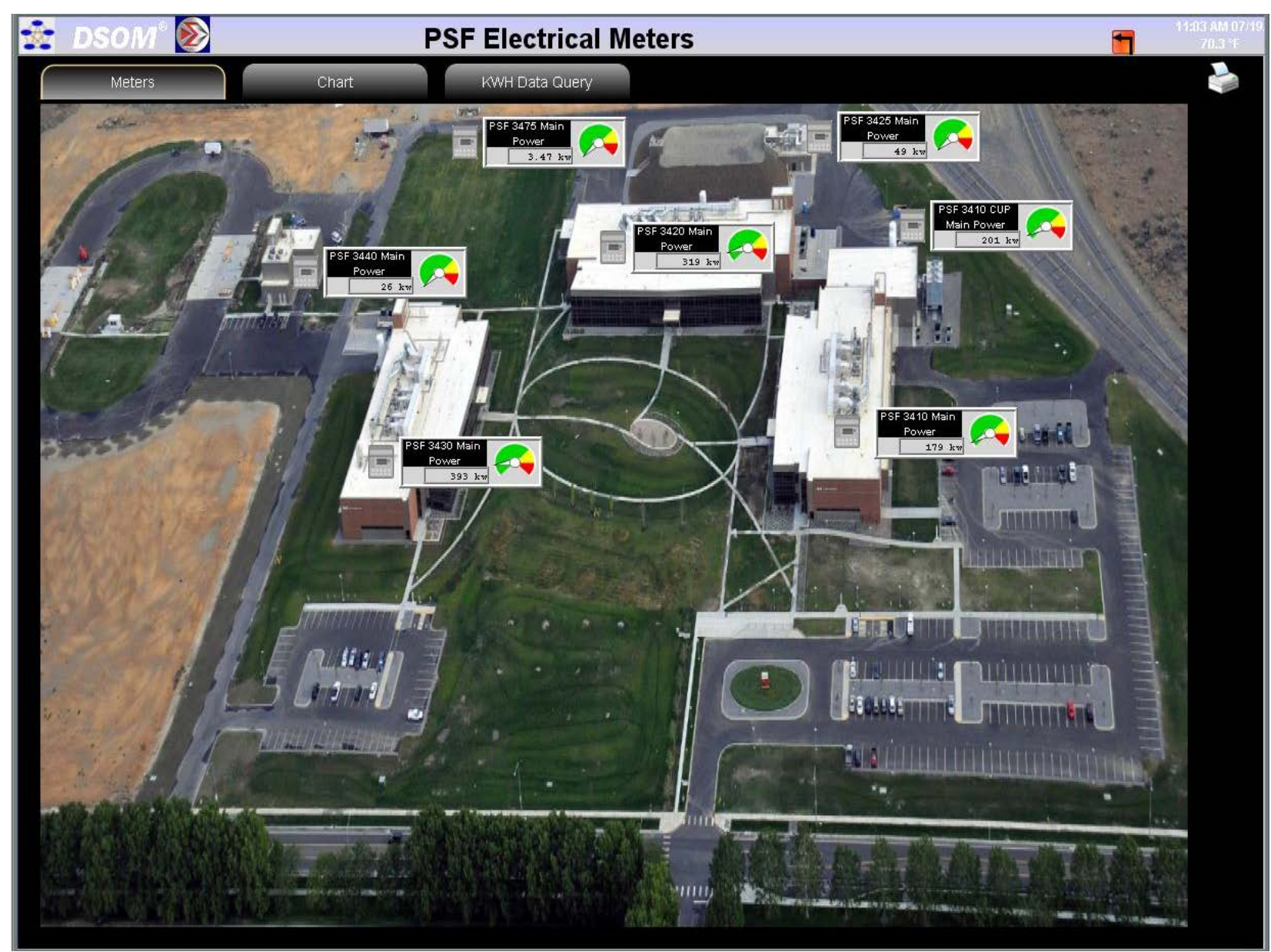

Figure 3. DSOM - PSF Electric Screen

Modeling will assist with automating the comparison of current data with historical data to establish the significance of noted differences. When a significant change is noted that cannot be explained by current weather conditions, an effort will be made to find out the reason(s) why, even if the change is beneficial. If a deleterious change in energy usage can be corrected with cost-effective energy efficiency measures, such measures will be implemented.

Other uses of these data include determining the need for recommissioning, validating electric bills, and diagnosing problems with equipment and systems operation. In addition, these data can be used to verify savings from energy conservation measures installed. 


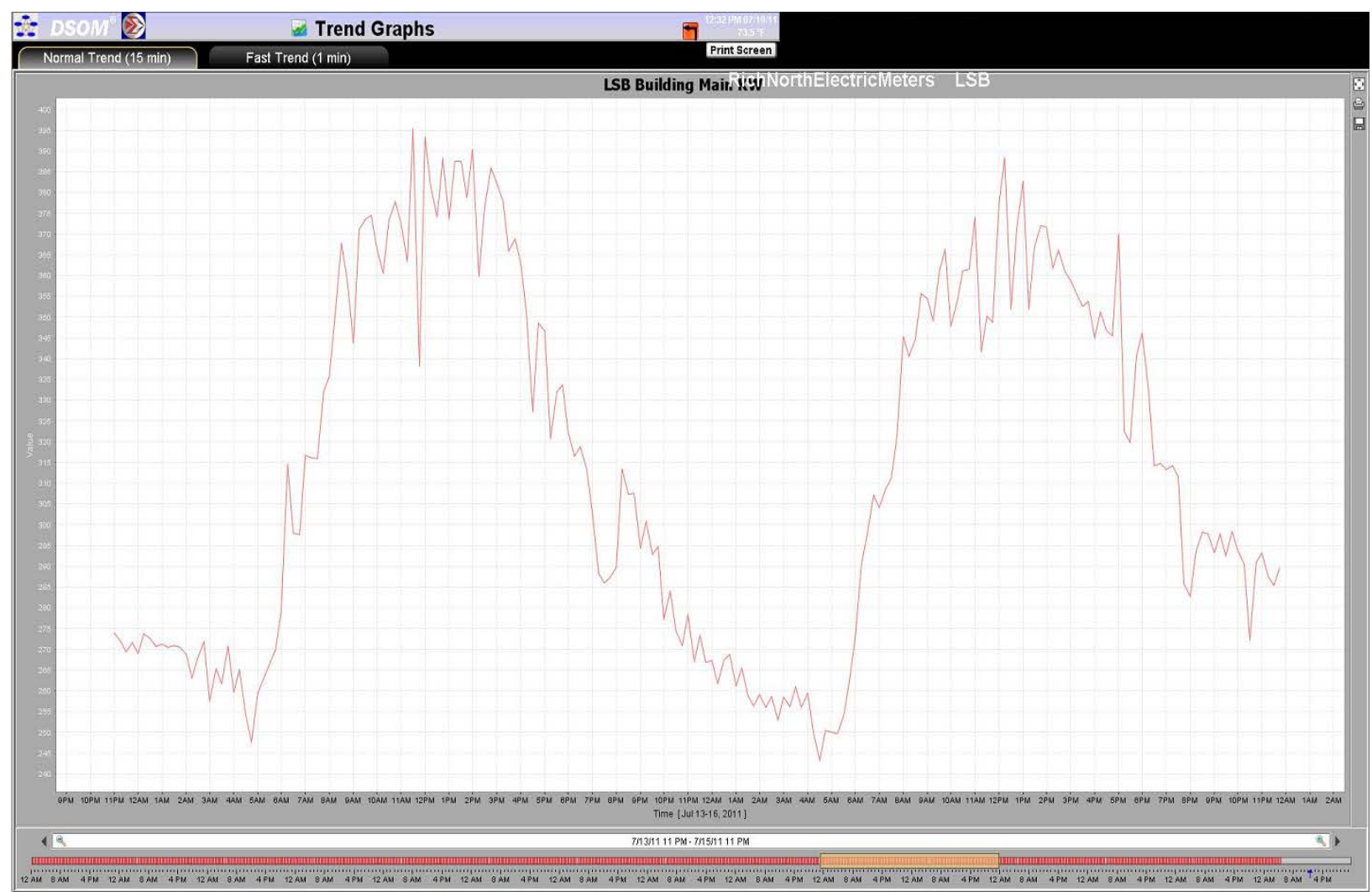

Figure 4. DSOM - LSB 2-Day Trend

In an effort to enhance the ability to model and analyze data received from the increasing number of meter related data points in the field a Building Operations Control Center (BOCC; Figure 5) was constructed in FY2011. The BOCC is located in the 350 Building and features twelve large monitors and two workstations. The idea behind the BOCC was to create a central nervous system for plant operations where energy saving opportunities and strategies could be identified and presented, and results could be verified. 


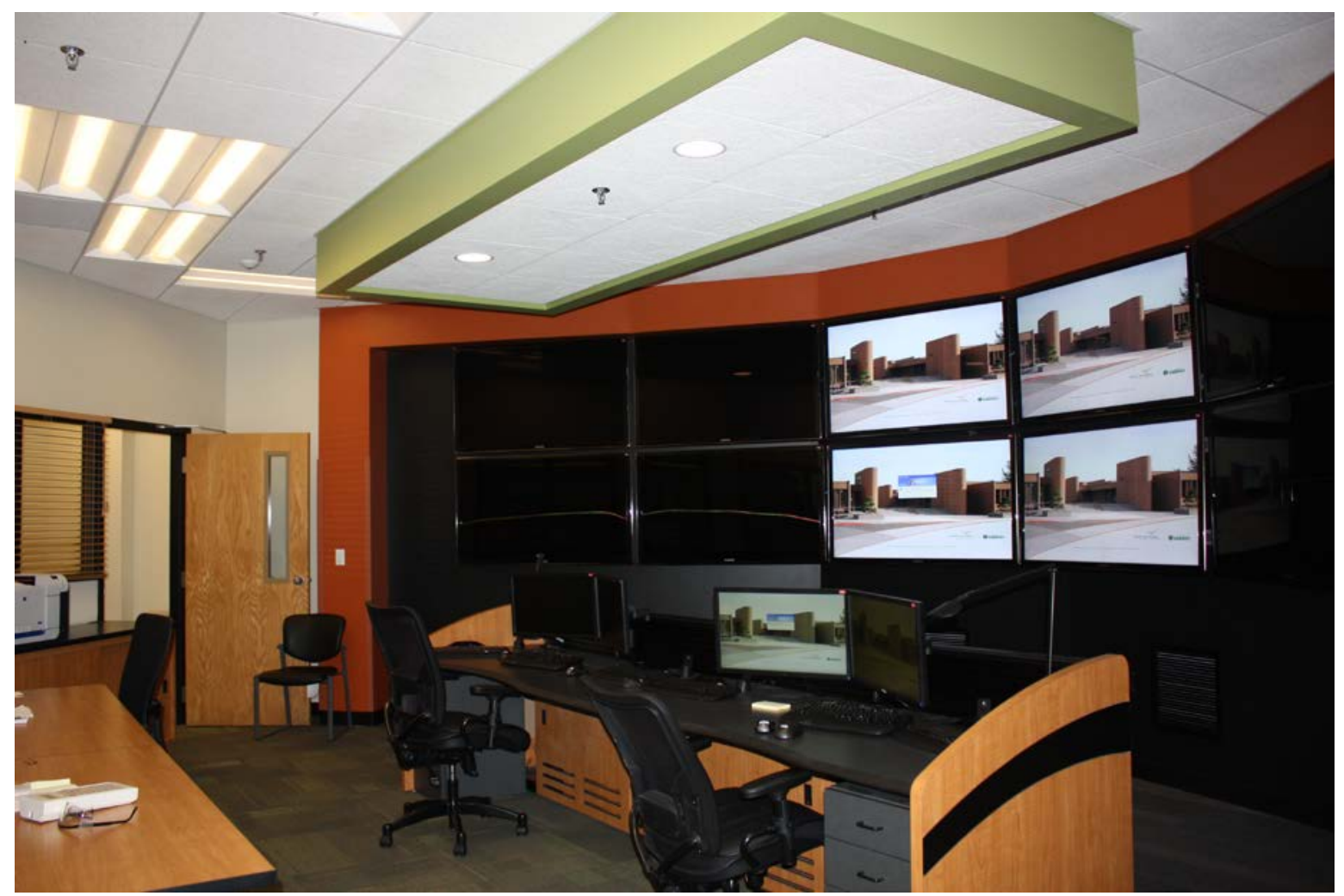

Figure 5. Building Operations Control Center

\subsection{Financing}

Financing to meter the buildings addressed in this plan has been provided by PNNL overhead expense funding. Incentive funding for metering is not available from Bonneville Power Administration (BPA) Energy Efficiency programs such as Conservation Rate Credit and Conservation Acquisition Agreements, either through BPA or the local utility (City of Richland). However, BPA may arrange for low-interest loans that are about 2 percent lower than Energy Savings Performance Contract loans if DOE guarantees payback on DOE buildings. While these incentive programs do not directly fund advanced metering, advanced metering is necessary to help identify energy efficiency measures in which incentives are provided. Advanced metering is also necessary to provide any energy savings verification required for incentives.

\subsection{Staffing}

PNNL reorganized the Facilities and Operations Division in FY 2011 to put more emphasis on plant operations and energy use and to use the advanced metering data.

The advanced metering program will require a thorough review to determine the appropriate staffing levels. Several staff currently function as part-time Resource Energy managers by evaluating monthly energy use data and coordinating corrective action with the power operators and building managers/ building engineers. This will be economically justifiable when the metering/monitoring program is fully implemented. 
Staff responsible for continued operations, maintenance, and analysis of the metering system and its data includes Jason Pope, Marc Berman, Norm Olson, Jack Burris, Ron Underhill, Steve Hultman, Wade Spence, and Kevin Schwartz.

\subsection{Reporting}

PNNL will report metering progress to DOE's FEMP through annual updates. Annual progress reporting is also part of the annual call for DOE's Annual Energy Management Report to the President and Congress, which reports on progress toward meeting the energy efficiency goals established by legislation, Executive Order 13423, "Strengthening Federal Environmental, Energy, and Transportation Management,” and DOE Order 430.2B.

\subsection{Conclusions}

This update shows that PNNL has made considerable progress on advanced metering installation (Table 1). The plan is to provide advanced electrical and natural gas metering on 96\% of the total EMS4 buildings square footage. To date, $100 \%$ of the electrical portion of the plan, which has a completion goal in 2012, has been completed. Natural gas metering, with a completion goal in 2016, is scheduled to be complete in 2012. In addition, advanced water meters have been installed in EMSL and the 300 Area Buildings. The leased buildings have standard water meters. PNNL will use the advanced metering data to monitor building energy and water use to improve energy and water-use efficiency for facility operation.

\subsection{References}

Energy Independence and Security Act of 2007 (EISA 2007). 2007. Public Law 110-140, as amended, Section 434(b).

Energy Policy Act of 2005 (EPAct 2005). 2005. Public Law 109-58, U.S. Department of Energy, Washington D.C.

Executive Order (EO) 13423. 2007. Strengthening Federal Environmental, Energy, and Transportation Management. Signed January 24, 2007.

DOE Order 430.2B. 2008. Departmental Directives Program, managed by the Office of Information Resources (MA-90), U.S. Department of Energy, Washington D.C.

Sullivan GP, R Pugh, and WD Hunt. 2007. Metering Best Practices, A Guide to Achieving Utility Resource Efficiency, October 2007. Federal Energy Management Program (FEMP), Office of Energy Efficiency and Renewable Energy, U.S. Department of Energy, Washington D.C.

Olson NJ. 2007. Metering Plan for Monitoring Whole Building Energy Use in PNNL EMS4 Buildings. PNNL-16740, Pacific Northwest National Laboratory, Richland, Washington. 
Olson NJ, MJ Berman, and DR Schielke. 2008. Metering Plan for Monitoring Energy and Potable Water Use in PNNL EMS4 Buildings. PNNL-17916, Pacific Northwest National Laboratory, Richland, Washington.

Olson NJ, MJ Berman, and DR Schielke. 2009. Metering Plan for Monitoring Energy and Potable Water Use in PNNL EMS4 Buildings. PNNL-18786, Pacific Northwest National Laboratory, Richland, Washington.

Olson NJ, MJ Berman, and DR Schielke. 2010. Advanced Metering Plan for Monitoring Energy and Potable Water Use in PNNL EMS4 Buildings. PNNL-19651, Pacific Northwest National Laboratory, Richland, Washington. 



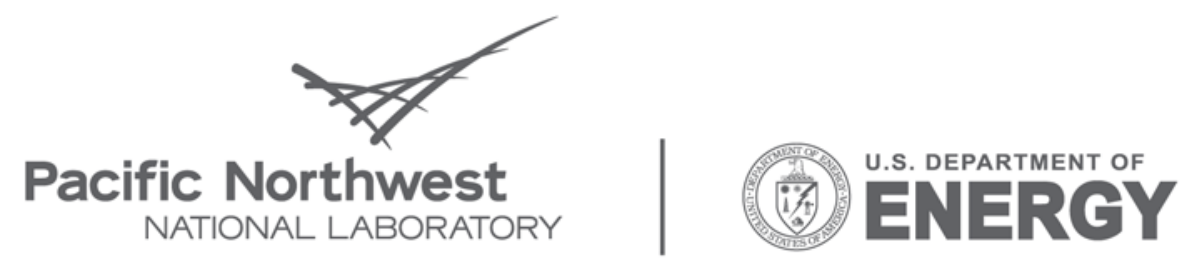

Proudly Operated by Battelle Since 1965

902 Battelle Boulevard

P.O. Box 999

Richland, WA 99352

1-888-375-PNNL (7665)

www.pnl.gov 